\title{
REPENSAR LA COMUNICACIÓN \\ PARA EL DESARROLLO
} RETHINKING COMMUNICATION FOR DEVELOPMENT

[ VENU ARORA ]

Doctoranda del Royal Melbourne Institute of Technology, Melbourne, Australia. M.A. en Mass Communications, Jamia Millia Islamia

University, Nueva Delhi, India. Lideró la división de comunicaciones del Programa de Naciones Unidas para el desarrollo (UNDP) en el Sur y Sureste asiático. Es directora ejecutiva de Ideosync Media Combine. varora国ideosyncmedia.org

Recibido: octubre 10 de 2014 Aceptado: octubre 31 de 2014 
El siguiente texto es la transcripción de la intervención de la profesora Venu Arora en la conferencia de la Asociación International para la Investigación en Medios y Comunicación (IAMCR, por sus siglas en inglés), que tuvo lugar en Hyderabad (India) en 2014. Como directora ejecutiva de Ideosync Media Combine, una iniciativa que integra metodologías comunicativas en pro del cambio social, expone brevemente dos experiencias ejemplares de comunicación para el cambio social, mientras que discute cuestiones críticas alrededor de la práctica de la Comunicación para el desarrollo e ideas acerca de la voz y la justicia social.

Palabras clave: Comunicación para el cambio social, desarrollo, discurso basado en derechos, poder, participación, justicia social.

\section{ABSTRACT}

The following text is the transcript of professor Venu Arora's intervention at International Association for Media and Communication Research (IAMRC), which took place at Hyderabad (India) in July 2014. As the Executive Director of Ideosync Media Combine, an initiative that integrates participatory communication methodologies for social change, her intervention discusses briefly two exemplary experiences involving Communication for Social Change while raising critical questions around Development Communication practice and ideas of social justice and Voice.

Keywords: Communication for Social Change (C4SC); Development; Rights based discourse; power; Participation, social justice

Compañeros panelistas, amigos:

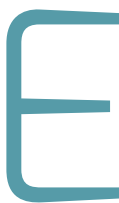

$s$ un privilegio formar parte de tan distinguido panel $^{1}$. Me siento agradecida por la oportunidad de compartir nuestro trabajo y mis reflexiones sobre la Comunicación para el desarrollo con todos ustedes.

De los diez minutos con los que cuento, me gustaría tomar un par para esbozar brevemente la historia de nuestra organización y el trabajo que hemos realizado, luego servirme de dos iniciativas específicas en las que estamos trabajando en el momento para enmarcar mis reflexiones y observaciones sobre la práctica de la Comunicación para el desarrollo y emplear el último par de minutos en el planteamiento de algunas preguntas acerca de nuestra discusión de hoy.

En Ideosync Media Combine ${ }^{2}$, trabajamos en la comunicación para el cambio social y concebimos un mundo en el que todas las comunidades estén facultadas con habilidades,

1. Otros panelistas eran: Rafael Obregón, presidente de Comunicación para el desarrollo de Unicef; Vinod Pavarala, profesor y Presidente de Medios comunitarios de Unesco; Jo Tacchi, decano substituto en investigación e innovación del Royal Melbourne Institute of Technology, Australia; Amparo Cadavid, decana de la Facultad de Ciencias de la Comunicación, UNIMINUTO, Colombia.

2. Ideosync Media Combine es una organización india sin ánimo de lucro que trabaja en la comunicación para el cambio social. Hace uso de la investigación participativa intensiva, basada en metodologías y nuevas tecnologías de medios a través de innovaciones comunitarias. herramientas y tecnologías de comunicación que les permitan acceder y hacer uso de la información así como crear y compartir conocimientos con otras comunidades a nivel local y global.

Ideosync inició labores a mediados de los noventa con el objetivo de innovar con la práctica de la comunicación en asociación con las comunidades, a medida que se tomaban pequeños pero significativos pasos hacia el cambio social. Recuerdo un suceso especial que se dio en nuestros inicios, en aquellos primeros días, cuando una gran organización para el desarrollo nos contactó y nos presentó su programa de Salud Adolescente. Desde la dirección principal del programa se nos dijo: "Quisiéramos crear historietas para los jóvenes. Ésta será una forma entretenida de entregarles información relacionada con salud. Y ya que lamentablemente el programa llega a su fin este año, nos encantaría producirlas e implementarlas en el curso de los siguientes tres meses".

Ahora bien, adoro las historietas, como de seguro muchos jóvenes lo hacen, pero había un error de fondo en convocar a una organización para la comunicación durante el proceso de finalización del programa de desarrollo con el propósito principal de crear material de comunicación, con poco tiempo para investigar sobre su diseño, y mucho menos planear su valor con relación a los resultados generales en comunicación, sin mencionar los correspondientes en materia de desarrollo para el programa. 
Resulta significativo que hasta el día de hoy recibamos nos encontramos en la capacidad de evitar tal tipo de compromisos o insistir en propuestas diferentes. La comunicación fue, y me atrevo a decir que es aún, un elemento secundario para la planeación del “desarrollo". Intentaré compartir mi concepto con relación a la problemática noción de desarrollo en unos pocos minutos.

Nuestro trabajo en Ideosync ha crecido de forma sistemática través de nuestra labor en India, en el sur de Asia y más allá, a partir del reconocimiento de la necesidad de fomentar capaparticipativas, hasta la promoción y el trabajo de otras partes interesadas en la creación y habilitación de un ambiente político y social para los medios de comunicación comunitarios en India.

Quisiera compartir dos ejemplos de nuestro trabajo: Muchos de ustedes pueden haber escuchado acerca de las peticiones similares, con la diferencia de que en el momento cidades; desde la planeación de la comunicación y evaluación

de Radios Comunitarias para la Protección Ambiental. Las estaciones radiales están emitiendo programas de formato largo que tratan muchos de estos asuntos con títulos que, más allá de tratar los aspectos sociales, hablan de las dinámicas políticas y de poder implícitas en las causas reales del desastre del año pasado. Una de las series radiales se llama En nombre del desarrollo, otra recibe el nombre de El agua vive bajo el árbol de hojas anchas, y el tercero, desarrollado por una estación radial urbana, lleva como nombre La Ciudad de mis sueños, ya que cuestiona las construcciones sin planeación adecuada en la ciudad de la montaña.

Ninguno de los programas que las estaciones llevan a cabo en esta primera etapa habla de desastre.

En otro escenario más previsible, que muchos de los que conocemos el mundo de la Comunicación para el desarrollo podemos imaginar bien, todas estas estaciones estarían desarrollando programas para proveer información sobre intervenciones antes, durante y tras los desastres, y lo que la comunidad debería hacer o no en tales momentos.

Otro ejemplo del trabajo que hemos venido realizando es la plataforma virtual llamada Community Media Manch y su aplicación móvil asociada. Después de una década de trabajar con estaciones de radio comunitarias a través de toda la India, hemos encontrado que las cur-

inundaciones que azotaron el estado de Uttarakhand en el norte de India en junio del año pasado. Se han dado numerosas discusiones en el país con respecto al papel de las estaciones de radio comunitarias en la atención de desastres. Hemos estado trabajando con tres estaciones radiales comunitarias en Uttarakhand durante más de seis años y aprovechando la oportunidad para involucrarnos en un diálogo sobre planeación y actuación adecuada. Sin embargo, no lo hemos hecho solos ya que invitamos a otros miembros de la sociedad civil pertenecientes al movimiento ambiental. El proceso de capacitación e intercambio de habilidades entre grupos radiales comunitarios, activistas ambientales y ONG condujo a discusiones en torno al origen del desastre y de las inundaciones, la definición de cambio climático y su impacto actual sobre el cinturón del Himalaya, el aporte real que la construcción de represas y vías de gran tamaño, que a la vez consumen los manantiales naturales y bosques, representan para la región, sobre lo que está en juego, y quiénes se benefician del desarrollo de estos enormes proyectos de desarrollo. Los reporteros radiales de la región fueron al campo, discutieron con sus comunidades estos temas y luego trabajaron, con nuestro apoyo, en las transcripciones y en el diseño de los programas radiales.

Siete estaciones radiales comunitarias en Uttarakhand, junto con dos grupos ambientales, forman hoy el Consorcio vas más rápidas de aprendizaje se dieron cuando los equipos radiales se reunieron. ¿Cómo pueden sostenerse tales oportunidades de aprendizaje con mayor frecuencia? El diseño de la aplicación Manch, en línea y móvil facilita el aprendizaje, la colaboración, la creación conjunta, y el compartir. Las estaciones radiales están descubriendo lo que significa colaborar y cómo pueden capacitarse unas a otras a través de la exposición de sus experiencias en radiodifusión y de sus tácticas para estimular el compromiso en las comunidades. Sus diálogos son una exploración del contexto y de las capacidades propias de cada una. Comparten contenido pero también ideas.

En otro escenario de Comunicación para el desarrollo más previsible, la nueva tecnología, el internet y los dispositivos móviles se utilizarían en la difusión de información y retroalimentación. Quizás incluso en la administración de un módulo de capacitación.

Estos previsibles y plausibles escenarios alternativos se prestarían más para evaluaciones de impacto.

El punto al que quiero llegar a través de estos dos ejemplos y su contraposición con escenarios alternativos es que si reconocemos la tensión entre las aspiraciones de la comunidad y las agendas de desarrollo, la dinámica del discurso del poder y los derechos, las ideas de libertades, la agencia y los habitantes de un mundo en constante cambio, sea que se encuentren en 
áreas urbanas o rurales, entonces tendremos que examinar y definir de nuevo los valores que enmarcan la labor actual de la Comunicación para el desarrollo.

Otro aspecto que quisiera resaltar rápidamente es el arraigo de la teoría de la Comunicación para el desarrollo en la génesis de su modernización a pesar del reconocimiento de las limitaciones de tales enfoques. Como alguien que trabaja primordialmente con comunidades y que ha tenido el privilegio de involucrarse con los numerosos aspectos del discurso teórico de la comunicación durante el desarrollo de sus estudios doctorales, ha resultado liberador dilucidar algunas de las tensiones que impiden la creación de un marco adaptable.

Lo que voy a sugerir puede sonar radical y provocador, pero me pregunto:

1. ¿No es este el momento de distanciarse de la evaluación de 'necesidades' y de impacto y hallar una manera del todo diferente de analizar lo que estamos haciendo y qué tan efectivo es? Porque en mi opinión, hay desigualdades de poder inherentes al diseño de estas metodologías de evaluación, al menos en la manera en que se practican actualmente en grandes programas de Comunicación para el desarrollo, apoyados y financiados por importantes organizaciones donantes. La palabra 'necesidad' en sí misma es un derivado del Estado del bienestar que elimina la agencia. Incluso si acuñáramos otro término, es así cómo trabajamos con comunidades para establecer procesos de cambio a través del diálogo que impacte.

2. Tal vez necesitamos examinar de nuevo el 'negocio' del desarrollo que funciona a través de solicitudes de propuestas y licitaciones ${ }^{3}$ que ni son transparentes, ni fomentan sociedades, sino que crean proveedores.

En tercer lugar, y quizás más importante, ¿no debería existir flexibilidad y un mayor alcance para movimientos horizontales en los diversos parámetros de desarrollo que, en la actualidad y en el pasado, se han servido de silos verticales en materia de salud, educación, sustento, medio ambiente, etc., lo que ha ocasionado parálisis de la planeación participativa y de los enfoques ascendentes? Porque tal como lo expresaron varios oradores durante el día de ayer, así como también el profesor Castells en su discurso inaugural, la vida real está "conectada en red" y al tratar estos objetivos de desarrollo como algo distinto y por separado, además de intentar medirlos de la misma forma, partimos de la superficie de la situación y no de su raíz.

3. Las peticiones de propuestas son puestas en procesos competitivos por parte de las Naciones Unidas y otras organizaciones multilaterales. Con frecuencia estos procesos no son transparentes en el sentido de no integrar los servicios de organización sobre un proyecto de base. Usualmente las organizaciones deben ser registradas en listas de ventas a fin de ser elegibles para las aplicaciones.
Por último, tanto el teórico practicante como el practicante teorizador necesitan encontrarse y sólo a través del trabajo colaborativo será posible encaminar nuestro trabajo hacia una respuesta comunicativa que sea en cierta medida adecuada para el mundo cambiante que habitamos hoy.

Conocí a un alto exfuncionario días atrás, quien encabeza actualmente un importante movimiento político de reformas democráticas en India, y quien afirmó que mientras el cambio social demanda tiempo, India no cuenta con él. Me gustaría unirme a su sentido de urgencia y añadir: el mundo no cuenta con tiempo para reconocer las posibilidades de cambio social que sabemos que la comunicación crea, si tan solo dejáramos de trazar los mismos caminos... ya que siempre es mejor cometer nuevos errores que repetirlos. 


\section{RETHINKING COMMUNICATION FOR DEVELOPMENT}

[ VENU ARORA ]

Fellow Panel members, friends:

$\mathrm{t}$ is my privilege to be on such a distinguished panel $^{4}$; and I am grateful for this opportunity to share our work and my reflections on Communication for Development (C4D) here with all of you.

First, I would like to briefly sketch out the history of our organization and the work we have done. Then use two specific ongoing initiatives that we are currently working on in order to frame the reflections and observations I have on $\mathrm{C} 4 \mathrm{D}$ practice.

So at Ideosync Media Combine ${ }^{5}$ we work on Communication for Social change and envision a world where all communities are empowered with communication skills, tools and technologies enabling them to access and use information as well as create and share knowledge with other communities locally and globally.

Ideosync began its work in the mid 90's looking to innovate with communication practice in partnership with communities - taking small and meaningful steps towards social change. I recall a particular incident, in those early days, when we were called in by a Large Development Organization and introduced to their Adolescent Health program. The senior program manager said: 'We would like you to develop comic books for the young people. That will be an entertaining way to give them health information. And unfortunately since the program closes this year we would like these produced and implemented in the next three months!'

I absolutely love comics and I am sure many young people do too - but there was something fundamentally wrong with a Communication Organization being called into the process towards the end of the development program primarily to create only the communication materials with little time to research the design of the materials, let alone plan its value for the overall communication outcomes, not to speak of the developmental outcomes of the program.

4. Other panelists included: Rafael Obregon, Chief, Communication for Development, UNICEF; Vinod Pavarala, Professor and UNESCO Chair on Community Media, at the Department of Communication, University of Hyderabad: Jo Tacchi, Deputy Dean Research and Innovation, Royal Melbourne Institute of Technology, Australia; and Amparo Cadavid, Dean, Faculty of Communication Sciences, UNIMINUTO, Colombia.

5. Ideosync Media Combine is an Indian not-for-profit organization working on communication for social change using intensive participatory research based methodologies and media new technology through community innovations.
We still get similar requests, but only now we are able to either resist such engagement or insist on different approaches. Communication was, and I dare say, still remains an afterthought when planning 'development', and I will try and share with you my thoughts on the problematic notion of development in just a few minutes.

Our work at Ideosync has grown iteratively through working in India, south Asia and beyond - from realizing the need for capacity building, participatory communication planning and participatory evaluation, to advocating for and working with like-minded stakeholders, towards creating an enabling political and social environment for Community Media in India.

I would like to share two examples from our work. Many of you may have heard of the floods that ravaged the northern state of Uttarakhand in India in June last year. There have been several discussions in the country - regarding engaging community radio in disaster response. We have been working with three community radio stations in Uttarakhand for over six years and used the opportunity to engage them in a dialogue on appropriate planning and action. However, we did not do this alone. We invited other civil society members from the environment movement into the process. The training and capacity sharing process between the Community Radio groups, the environment protection activists and NGOs led to discussions around question such as: Why the disaster and floods happened? What was climate change and how was it impacting the Himalayan belt? The building of large dams and roads that eat up the natural springs and forests, are really developing the region? What is at stake? Whose development are the large development projects for? The radio station reporters went into the field, engaged with their communities on these questions and then worked with our support on scripts and radio program designs.

Seven Community Radio Stations in Uttarakhand today, together with two environment groups, form the Community Radio Consortium for Environment Protection. The radio stations are making long form radio program series, addressing several of these issues with titles that speak of not just the social but the embedded political and power dynamics of what really caused the disaster last year. One Radio Program series is called 'In the name of Development'. Another one is titled 'Water lives under the tree with broad leaves'. A third one by an urban Radio station is called 'The City of my dreams', questioning the unplanned constructions in the hill city. None of the programs the Community Radio stations are making, talked in this first phase about disaster. 
In another, more predictable scenario, that many of us who know the $\mathrm{C} 4 \mathrm{D}$ world can well imagine, all these stations would be making programs that provided information on pre, during and post disaster interventions, and what the community should or should not do in times of disaster.

Another example from our ongoing work is the online platform called Community Media Manch and its associated mobile application. From nearly a decade of working with Community Radio stations across India, we found that the fastest learning curves happened when the Radio station teams met each other. How could these learning opportunities be made more frequent and sustained? The Manch online and mobile-based application is designed to facilitate learning, collaboration, co-creation and sharing. The radio stations are discovering what it means to collaborate and how they can train each other through sharing their broadcasting practice and community engagement tactics. Their dialogues are an exploration of each other's context and capacities - they share content but they also share ideas.

In another more predictable C4D scenario, new technology, the internet and the mobile would be deployed for information dissemination and feedback. Perhaps even deliver a training module. These predictable alter-

nate and plausible scenarios would also have lent themselves better to impact assessments.

The point I want to make through these two examples, and the contradicting alternate scenarios, is that if we recognize the tensions between com-

munity aspirations and development agendas, the dynamics of power and Rights based discourse, the idea of freedoms, agency and the citizens of a changing world whether they live in rural or urban spaces, then we will have to relook and redefine the values embedded in C4D work as it exists today.

Another issue that I just want to raise very quickly, is that the theory of Communication for Development continues to be rooted in its modernization genesis despite repeatedly acknowledging the limitations of those approaches. As someone who is primarily working with communities and having had the privilege of engaging with the many strands of communication theoretical discourse during my ongoing doctoral study, it has been liberating to tease out through my practice some of the tensions that prevent an adaptive framework.

What I am going to suggest may sound radical and provocative, but I ask:

First, is it not time to move away from 'needs' assessments and impact assessments and find a different way altogether to look at what we are doing and how well we are able to do it? Because to my mind, there are inherent power inequities in the design of these assessment methodologies - at least in the ways that they are currently practiced in large C4D programs supported and funded by big Donor organizations. The word 'need' itself is a derivative of the welfare state that takes away agency - and even if we were to coin a different word - it is how we work with communities to establish the processes of change through dialogue that matters.

Secondly, perhaps we need to re-look at the 'business' of development that function through RFPs and Bids ${ }^{6}$, which are neither transparent nor foster partnerships but rather create vendors.

Thirdly and perhaps most importantly, should there not be flexibility and more scope for horizontal movement across the diverse parameters of development that are currently - and have over the past - been in vertical silo's of Health, Education, livelihoods, Environment, etc., thereby crippling participatory planning and bottom up approaches. Because as has been said by speakers in various sessions yesterday and by Professor Castells in his inaugural address, real life is 'networked' and by treating these Development Goals as distinct and separate and trying also to measure them as such we force the agenda from

\section{Real life is 'networked' and by treating these Development Goals as distinct and separate and trying also to measure them as such we force the agenda from the top rather than let it emerge from the bottom}

the top rather than let it emerge from the bottom.

Lastly, practicing theoretician or theorizing practitioner the two need to meet and only through collaborative action will we be able to work towards even a half way adequate communication response to the changing world that we live in today.

I met a senior ex bureaucrat a few days ago who is spear heading a significant political movement for democratic reforms in India, who said that while social change takes time, India does not have the luxury of time. I would like to echo his sense of urgency and say: the world does not have the luxury of time to realize the potential we know communication has for fostering social change - if only we stop treading old pathways - for it is always better to make new mistakes rather than repeat old ones.

6. Request for proposals are put out my UN and other multilateral organizations in a competitive process, often not transparent that engages the services of organization on a project basis. Often organizations must be registered in vendor lists of these organizations in order to be eligible to apply. 